\title{
Review of the Main Criteria in Hadith Website Development
}

\author{
Usan Usan \\ UIN Sunan Gunung Djati Bandung \\ sanofficial10@gmail.com \\ Mujib Hendri Aji \\ UIN Sunan Gunung Djati Bandung \\ mujibhendri@gmail.com
}

\section{Suggested Citation:}

Usan, Usan and Aji, Mujib Hendri. (2021). Review of the Main Criteria in Hadith Website Development, Volume 1, Nomor 2: pp 176-182. http://dx.doi.org/10.15575/jis.v1i2.11802

\section{Article's History:}

Received February 2021; Revised April 2021; Accepted April 2021.

2021. journal.uinsgd.ac.id @. All rights reserved.

\begin{abstract}
Abstrak:
Artikel ini bertujuan untuk mengkritisi, E-Proceeding Khadher Ahmad, Ishak Hj. Suliaman, Faisal Ahmad Syah dan Ibrahim Adham dengan Judul Kriteria Utama dalam Pembuatan Website Hadits: Satu Analisis dan Cadangan. Metode yang digunakan dalam skripsi ini adalah analisis deskriptif dengan mengkaji dan menganalisis (1) isi teks hadits yang tersusun utuh; (2) terjemahan hadits yang telah diperiksa; (3) sumber hadits dan takhrij; (4) pemahaman hadits singkat; (5) organisasi atau panel bertanggung jawab dan memiliki kelayakan; (6) antarmuka yang ramah pengguna; (7) keterikatan riwayat al-asanid (pemetaan sanad hadits); (8) menyusun tema kelompok hadits; (9) pembagian hadits berdasarkan kitab jawi; dan (10) menyediakan hadits alternatif untuk hadits palsu. Dari sepuluh kriteria pembuatan website, menurut kami tidak semuanya bisa direkomendasikan.
\end{abstract}

\section{Kata Kunci: Hadits, Website, Matan, Sanad}

\begin{abstract}
:
This paper aims to criticize, E-Proceeding Khadher Ahmad, Ishak Hj. Suliaman, Faisal Ahmad Shah and Ibrahim Adham with the Title of Main Criteria in Hadith Website Development: One Analysis and Reserves. The method used in this paper is descriptive analysis by reviewing and analyzing (1) the content of the hadith text which is in full line; (2) translation of the hadith that has been examined; (3) hadith sources and takhrij; (4) brief hadith understanding; (5) the organization or panel is responsible and has eligibility; (6) user friendly interface; (7) attachment of history al-asanid (mapping sanad hadith); (8) laying out the hadith group theme; (9) distribution of hadiths based on the book of jawi; and (10) providing alternative hadiths to false hadiths. Of the ten criteria for website development, we can recommend not all of them in our opinion.
\end{abstract}

Keywords: Hadith, Website, Matan, Sanad

\section{INTRODUCTION}

Cyber systems with computer connectivity and network infrastructure worldwide are connecting human activities in managing information in the development of the digital era, in this process involving automation between digital devices such as cloud computing, Internet of Thing (loT) and Cognitive Computing. These services make information technology accessible and empowered with a wide range via the internet network, always available anytime and anywhere (always on) with cloud computing-based storage media that provides online storage services, even large amounts of data with technology capable of managing and much data or commonly called Big Data, all of this is managed intelligently with the Cognitive Computing feature and the internet becomes a link for every human activity on the internet such as accessing, creating and distributing internet content on various computer media using devices or various other types of computers. This capability is technically very closely related to the development of web technology with User Generated Content Platform services as a tool that launches digital content is one of the developments in loT (Sulianta \& Supriatna, 2020). The definition of the website itself is a collection of a number of pages on the internet, in which discusses related topics that represent information. The website has a function as a 
representation of a person, organization or related institution. Anything can be poured in the form of a website (Ginanjar, 2014). One of them is the Hadith website.

Hierarchically the Sunnah is a reference source after the Qoran. Its existence is marja'iyah al- 'ulya Islamic teaching. Therefore, the Prophet's hadith is included in the ilahiyah realm (Dalimunthe, 2009). Hadith criticism should like scientific criticism in general, requires principles for empirical factual knowledge as a basis for thought, Muhammad 'Abid al-Jabiri stated that a critique that is not based on factually empirical as the basis of the subject will only leave ideological criticism for ideology and leave nothing except ideology. For that, we need criticism that is in accordance with scientific requirements, namely criticism aimed at production events (mode of production) a kind of theory that has the application of mental action. Such criticism can provide a pathway for an objective scientific reading. Hadith criticism should be open, can be retested for its validity (testability) and not trapped in ideological-subjective circles that cause violations of the criticism principles and judgment such as validity, reliability, transparency, fairness and authenticity (Idris, 2020). In hadith criticism, sanad criticism is usually referred to as external criticism (al-naqdu al-khāriji), while matan criticism is usually called internal criticism (al-naqdu al-dākhili) (Zuhriah \& Shilviana, 2020). From the understanding of the web and the hadith above, the writer concludes that the meaning of the hadith website is a number of pages on the internet that discuss the hadith in it, and present anything related to the hadiths both sanad, eye, translation and syarah.

In the E-Proceeding of the 4th International Muzakarah \& Mu'tamar on Hadith (IMAM 2019) on November 20, 2019 written by Khadher Ahmad, Ishak $\mathrm{Hj}$. Suliaman, Faisal Ahmad Shah and Ibrahim Adham from the University of Malaya Kuala Lumpur with the title Main Criteria in Hadith Website Development: One Analysis and Reserves which resulted in research that there are ten important criteria that must be contained in the development of a hadith website (Khadher Ahmad, 2019).

The explanation above is the background for the author to study, review and analyze whether the important criteria in the development of the Hadith website in the E-Proceeding can be a recommendation that will be used by many people later.

\section{METHOD}

This research used analytical descriptive, i.e., a research process that brings how data is organized into a description, category, and basic description section of the search by exploring and systematically presenting data obtained from the results of data collection such as interviews, documentation and field notes (Mustari \& Rahman, 2012). The data was organized into categories, explain into units, make a composition or combination of parts, arrange according to the description of the frame of mind and choose which ones are considered the most important and will be studied, then draw conclusions so that they are easily understood by others and themselves (Anggito \& Setiawan, 2018).

\section{RESULTS AND DISCUSSION}

Research on the hadith of the Prophet Muhammad or commonly referred to by Muslims as Sunnah al-Nabawiyah, is a study that seems unending, whether it is studied from the material aspect (eyes), or from the transmission side (sanad). This illustrates how hadith in Muslims position is very important (Anam, 2016).

Rasulullah had anticipated the backwardness of the ummah and shaabah felt the same way. So they try to prevent and try various ways in the effort to preserve and maintain the hadith such as minimalism, verification, purification, clarification, and other efforts to maintain the authenticity of the hadith. Even since the Prophet was still alive, his shahabah had shown their efforts in protecting the Islamic heritage, especially religious texts. This starts from collecting the writings of the Qur'an and hadith collectively and personally, doing tabayyun if you get hadith from other friends, even doing criticism in order to maintain the purity of the text. Many of these friends, without hesitation, went straight to the Prophet to clarify and verify the hadiths obtained, from which the tradition of criticism emerged in the world of narration (Umar, 2011).

The muhaddithîn formulated several criteria for finding authentic traditions that were among the many traditions that were relied on by the Prophet. These criteria exist in two criticisms (naqd), namely external criticism (sanad) and internal criticism (matn) (Afwadzi, 2017).

The main criteria in developing the hadith website in the e-Proceeding of the 4th International Muzakarah \& Mu'tamar on Hadith (IMAM 2019) on November 20, 2019 written by Khadher Ahmad, Ishak Hj. Suliaman, Faisal Ahmad Shah and Ibrahim Adham from the University of Malaya Kuala Lumpur are:

\section{Contents of Complete Lined Hadith Text}

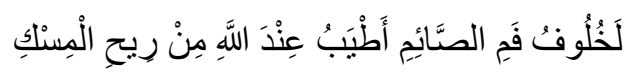

Meaning:

"The breath of a fasting person is more fragrant with Allah than the smell of Kasturi oil".

The complete hadith from the history of Imam at-Turmudzi no hadith 776 is below: 


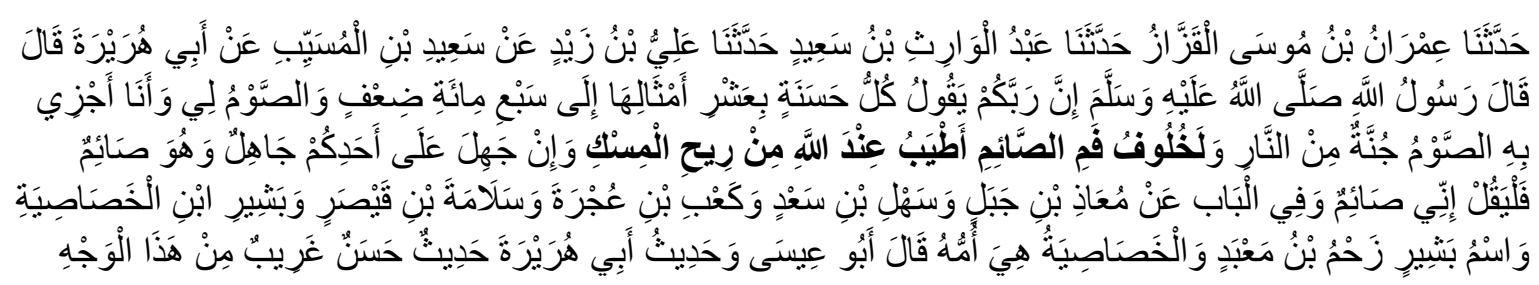

Meaning:

Have told us 'Imran bin Musa Al Qazzaz has told us' Abdul Waris bin Sa'id has told us Ali bin Zaid from Sa'id bin Al Musayyib from Abu Hurairah he said, Rasulullah said, "Verily your Rabb said: Every goodness is rewarded tenfold to seven hundred times, while fasting is for Me and I myself who will reward his fast (without a limit on the number of rewards), fasting is a shield from hellfire, and the smell of the mouth of a fasting person, more smell good with Allah instead of the fragrance of misk (perfumed oil) and if one of you asks you to quarrel even though he is fasting, then say that I am actually foaming. " In this chapter (there is also a narrative -pent) from Mu'adz bin Jabal, Sahl bin Sa'ad, Ka'ab bin Ujrah Salamah bin Qaisar and Basyir bin Khashashiyah. And Bashir was named Zahm bin Ma'bad but Khashashiyah was Bashir's mother. Abu 'Isa said, Abu Hurairah's hadith is a hasan gharib hadith from this route.

Takhrij Hadith

In the observance of criticism, the object to be examined is the hadith observation itself. Therefore, before conducting an eye criticism, it is necessary to first explain what it means. Etymologically, the word al-matn means mâ irta fa 'min al-ard (rising ground), or from the word tamnin al-qaws (binding a bow). Meanwhile, in terms of terminology, al-Suyûtî said a number of versions of the notion of matan which basically have the same substance. According to lbn Jam'ah, matan is a sentence where the sanad ends, or in a simpler sense, matan is the end of the sanad (ghâyat al-sanad). Meanwhile, according to al-Tîbî, matan is the material of the hadith or hadith lafaz itself (Irham, 2011).

The material about the criticism of the matan has become a special attraction for researchers, since the mutaqaddimin era to the present researchers. For example, as was done by Said Aqil Husen al-Munawwar in his work "The Method of Criticism of Matan Hadith According to Muhadditsin Mutaqaddimin's View" in the Ushuluna Journal, which discusses globally the finding of facts on the use of the method of criticism even since the time of sanad criticism has not been found, namely friends when Rasulullah was still alive in their midst (Al-Munawar, 2016). Many also discussed as part of the intellectual thought of figures, such as Muhammad al-Ghazali (Abdillah \& Mampa, 2019) (Kasban, 2017), Jamal al-Banna, Musthafa al-Siba'l (Juriono, 2017), Salahuddin al-Adlabi (Qayyum, 2015), Muhammad Tāhir Al-Jawābī (Qomarullah, 2018), then there are also those who conduct studies such as the writing of Atiyatul Ulya "Criticism of the Quality of Women Hadith Minds Weak Reasonable Perspective of Salahudin Ibn Ahmad Al-Adlabi" in Ushuluddin Journal (Ridwan Nurrohman \& Kosasih, 2010).

The observations of this hadith are supported by a matan with almost the same text, so that there is no syadz (Dalimunthe, 2009). to support this statement, it can be verified with data from another hadith narrated by Imam Muslim No. 1942 (No. 2362 in Syarh Sahih Muslim), such as:

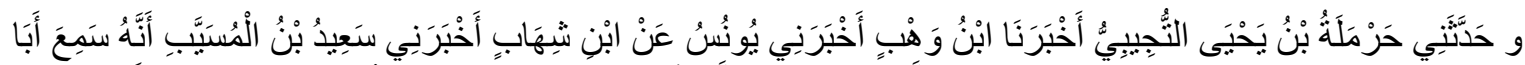

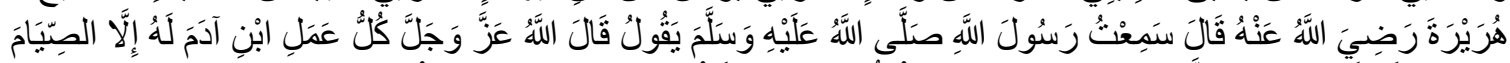

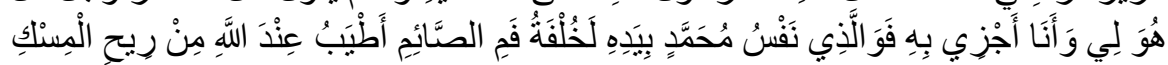

Meaning:

Has told me Harmalah bin Yahya At Tujibi has informed us Ibn Wahb has informed me Yunus of Ibn Syihab has informed me Sa'id bin Al Musayyab that he heard Abu Hurairah radhiallahu'anhu say; I heard the Messenger of Allah say, "Allah 'Azza wa Jalla has said;' Every deed of Adam's son is for him, except fasting, because he is for Me, and I will repay him. ' So for the sake of the Essence whose soul Muhammad is in His hands, indeed, the breath of a fasting person is more fragrant in the sight of Allah than the scent of musk." (Lasyin, 2002).

\section{The Hadith Translation That Has Been Thought}

According to Khadher Ahmad, Ishak Hj. Suliaman, Faisal Ahmad Shah and Ibrahim Adham:

"The content of the hadith text which is completely outlined is very important in exposing it to the crowd, with the main objective being to avoid errors in lines that may carry different meanings or different laws. Even directly, it can also help those who do not understand the Arabic language structure, or directly do not understand and read Arabic texts except those that are outlined like the text of the Qoran ".

Today's Arabic is faced with serious challenges. First, the lack of interest, motivation, and enthusiasm for learning through the doctrine of Arabic as a language that is difficult to learn and understand. The bad image of Arabic as an unattractive and difficult language to learn, according to research by Fathi Ali Yunus in Egypt in the 1980s, is partly because Western colonialization of the Islamic world is on the agenda of separating Muslims from the language of the Qoran. There is a study in Malaysia regarding the difficulty of learning Arabic in tertiary institutions (2005) which shows that the cause of the difficulty in 
learning Arabic is not due to the substance or material of Arabic, but there is no interest (100 percent), no Arabic background (87 percent), college curriculum materials (83 percent), difficulty understanding Arabic language material (57 percent), and an unsupportive classroom environment (50 percent). About 80 percent of psychological factors cause difficulty learning Arabic, (77 percent) of them have a negative impression of Arabic. Second, for reasons of belief and doctrine, the use of Arabic fushha (standard, formal) among the Arab community and social relations has also begun to diminish in its use and comparison, which tends to be replaced by 'ammiyah (everyday language) or local dialects (Saudi, Egyptian). , Syria, Sudan, etc.). Third, in Indonesia language politics has not fully provided good news for the existence of Arabic. Seeing the great potential of Muslims, naturally it can be used as a second language applied in Islamic education institutions, starting from primary school to university level. Fourth, in educational and learning institutions in Indonesia, Arabic has not fully yet have a strong theoretical foundation and framework, especially in terms of the curriculum and learning methodology (Yunus, F., 2015).

\section{Hadith Sources and Takhrij hadith}

According to Khadher Ahmad, Ishak Hj. Suliaman, Faisal Ahmad Shah and Ibrahim Adham:

"What is prioritized is the hadith edict that can be conveyed so that the reader or sailor knows firsthand the source of the hadith and its status."

The source of information is not only important but as a necessity because it is absolutely impossible if a situation can be disclosed when the origin or source is not known where it comes from, so that information in this case takhrij hadith can be conveyed and known by website visitors.

\section{Brief Understanding of Hadith}

Meaning:

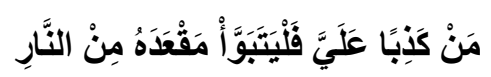

Anyone who lies on me has put himself in Hell.

The complete hadith is from the history of Imam Bukhari No. 105 (No. 108 version of Fathul Bari) are as follows:

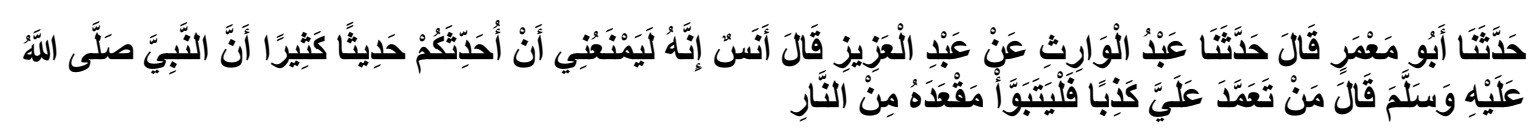

Meaning:

Has told us Abu Ma'mar said, told us' Abdul Warits from 'Abdul' Aziz said, Anas said, "Truly what prevents me from conveying to you many hadiths is the word of the Prophet," Whoever deliberately lies against me (on my behalf), then let him prepare his seat in hell. "

Takhrij Hadis

The observations of this hadith are supported by a matan with almost the same text, so that there is no syadz, to support this statement, it can be verified with data from other hadiths narrated by Imam Muslim No. 5 (No. 4 in Syarh Sahih Muslim), such as:

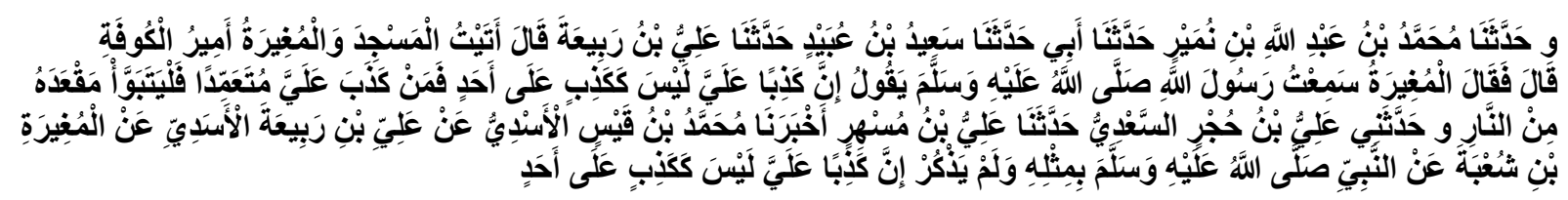

Meaning:

Has told us Muhammad bin Abdullah bin Numair told us that My Father told us Sa'id bin 'Ubaid had told us Ali bin Rabi'ah he said, "I went to the mosque while al-Mughirah, the governor of Kufa. He said, "Then al-Mughirah said, 'I heard the Messenger of Allah say," Verily lying on my behalf is not the same as lying on behalf of someone, whoever lied on my name intentionally then let him take his seat from hell. "And has told me Ali bin Hujr as-Sa'di has told us Ali bin Mushir has informed us Muhammad bin Qais al Asdi from Ali bin Rabi'ah al Asdi from al-Mughirah bin Syu'bah from the Prophet with such hadiths it's just that he didn't say, "Truly lying in my name is not the same as lying on someone's behalf." (Muslim, 2014).

According to Khadher Ahmad, Ishak Hj. Suliaman, Faisal Ahmad Shah and Ibrahim Adham:

"If there is the ability to explain in long conversations which can give a thorough understanding, it is very good. However, perhaps in explaining the hadith understanding, some fawa id or teachings or main contents that can be excluded from the hadith may be explained. Then list them one by one so that when the reader examines the hadiths, he can understand the hadiths indirectly.

If the website manager has the ability to explain in a long discussion, it will be able to provide a very good understanding comprehensively. But perhaps in explaining this, some fawa'id or teachings (core) of the hadith can be conveyed so that website visitors can understand the hadith indirectly. 


\section{Responsible and Eligible Organizations or Panels}

According to Khadher Ahmad, Ishak Hj. Suliaman, Faisal Ahmad Shah and Ibrahim Adham: "When many texts are entered, there are many possibilities to be exposed to errors and mistakes. With direct effort and cooperation within the organization, mistakes will be reduced as little as possible".

The more hadith texts that are submitted to the website, the more likely it is to be subject to errors. But if there is direct cooperation with related organizations or agencies, errors can be minimized, but it is also important to know the capacity of the web itself so that when entering the hadith into the database (MySQL) it does not exceed capacity.

\section{Friendly User Interface}

According to Khadher Ahmad, Ishak Hj. Suliaman, Faisal Ahmad Shah and Ibrahim Adham: "In this aspect, creativity is very important in presenting information and announcements that will be presented. Proficiency in building sophisticated, creative, and user-friendly websites is highly required so that anyone who is navigating can understand and retrieve information related to hadith more easily and quickly. In order to speed up the process of providing web pages with a good and up-to-date interface, it is reserved for cooperation with graphic designers and webpage designers who are engaged in this field. This collaboration will make the efforts to be made in the development of this web page more successful and will be a current web page for mutual benefit ".

In this aspect, creativity is also very important in presenting information. Skills in developing sophisticated, creative and easy websites for visitors to use so that they can understand and retrieve hadith-related information more easily and quickly. However, the involvement of web designers (web design) also has a very important role so that what is displayed on the website can be enjoyed in terms of its visual beauty and must also be considered / avoided against symbols that are contrary to Islam and it would be nice if that initial appearance contains a guidebook (manual book).

\section{Appendix Forms of Shajarah Al-Asanid (Mapping of Sanad Hadith)}

According to Khadher Ahmad, Ishak Hj. Suliaman, Faisal Ahmad Shah and Ibrahim Adham: "The exposure of Shajarah al-Asānid (mapping of hadith sanad) is important for a hadith website to cleanse the state of a hadith sanad in terms of sanad continuity. Then, to know for sure the condition of the transmitters of something hadith is problematic or not ".

The display of shajarah al-asanid (mapping the chain of hadiths) is also important for a hadith website to reveal the state of a hadith chain in relation to the continuity of the narrator and information about the narrator of a hadith is also very important whether it is problematic or not so that website visitors will understand the quality of the hadith.

\section{Putting Hadith Group Themes}

According to Khadher Ahmad, Ishak Hj. Suliaman, Faisal Ahmad Shah and Ibrahim Adham: "When referred to this theme, reviewers or visitors of the web page will continue to receive very detailed information regarding the hadiths from various sources, knowing the various and different narrations of hadith, the various sanads and various observations of the hadith text. This case indirectly helps in providing proper understanding ".

When referring to a certain theme, website visitors will immediately get information about the hadiths that will be searched for from various narrators, knowing the differences in hadith narratives, narrators, hadith observations and other parts. This will indirectly be very helpful in providing information for visitors who want to search for hadiths with certain themes.

\section{Distribution of Hadith Based on the Book of Jawi}

According to Khadher Ahmad, Ishak Hj. Suliaman, Faisal Ahmad Shah and Ibrahim Adham:" The division of hadiths based on the Jawi books or themes based on fields is important to make use of the works of previous scholars in the nusantara. During the same period, this hadith website could raise the existence of jawi books in the prime stream in Malaysia".

The distribution of hadiths based on the jawi books does not really need to be displayed on the website because if you want to refer to the context of the books in the nusantara, there will be a lot of it, but what needs to be considered is the quality of the authenticity of the author and more research is needed to ascertain whether the book was written properly or written by someone else, because it will lead to a difference in the written real meaning.

\section{Providing Alternative Hadiths To False Hadiths}

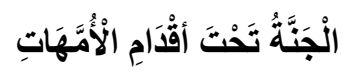

Meaning:

"Heaven is under the feet of the mothers".

The complete hadith from Anas ibn Malik's history is as follows:

from Abu Aly al-Hasan ibn Khalaf al-Wasiti, from Umar ibn Ahmad ibn Syahin, from Abd al-Wahid ibn Al-Muhtadi billah ibn al-Wasiqi, from Ali ibn Ibrahim al-Wasiti from Mansur ibn Muhajir from Abi an- Nadri al-Abbar from Anas ibn Malik said: "The Messenger of Allah said: Heaven is under the soles of the mother's feet." (H.R. Anas ibn Malik) 
Takhrij Hadith

1) Abu Aly al-Hasan ibn Khalaf al-Wasiti, his real name is Hasan ibn Khalaf ibn Ya'qub. Have a chew on Abu Ali or Abu alQasim. Has al-Bagdadi and al-Wasiti ratios. Have laqab al-Hakim. Including the 18th taqabah, died in Egypt and was assessed as tsiqqah. Ibrahim ibn Sa'id al-Habbali considered it a tsiqqah lakinnahu ibtali. The teachers are Abdullah ibn Ibrahim ibn Ayyub ibn Masi, Umar ibn Ahmad ibn Syahin, Muhammad ibn Ahmad ibn Muhammad ibn Yahya, and others. While his student was Muhammad ibn Salamah ibn Ja'far ibn 'Ali ibn Hukmun ibn Ibrahim ibn Muhammad ibn Muslim (Abu' Ali / Abu Abdullah).

2) Umar ibn Ahmad ibn Syahin, his real name is Umar ibn Ahmad ibn Usman ibn Ahmad ibn Muhammad ibn Ayyub ibn Yazdad ibn Siraj ibn Abdirrahman. Known as Umar ibn Syahin al-Wa'id. Born in $297 \mathrm{AH}$ and died in $385 \mathrm{AH}$, lived and died in Basra (Baghdad). Including the 16th tabaqah and considered tsiqah. The teachers were Abdul Wahhab ibn Isa, Abdullah ibn Muhammad ibn 'Abdusi and Abu Aly al-Hasan ibn Khalaf al-Wasiti, from Umar ibn Ahmad ibn Syahn, from Abd alWahid ibn al-Muhtadi billah ibn al-Wasiqi, from Ali ibn Ibrahim al-Wasiti from Mansur ibn Muhajir from Abi an-Nadri al-Abbar from Anas bin Malik and others. His students were Hasan ibn Khalaf ibn Ya'qub, Ahmad ibn Muhammad ibn Ahmad ibn Galib, Hasan ibn Ali ibn Abdillah and others. He is considered tsiqah, as-Suduq al-hafiz, tsiqah ma'mun.

3) Abd al-Wahid ibn al-Muhtadi billah ibn al-Wasiqi billah, his real name is Abd al-Wahid ibn Muhammad ibn Harun ibn Muhammad ibn Harun ibn Muhammad ibn Abdillah ibn Muhammad ibn Ali ibn Abdillah ibn al-Abbas. Died in $318 \mathrm{AH}$, including the 13th tabaqah and was assessed as suduq hasan al-Hadith. The teachers were Ja'far ibn Muhammad ibn Syakir, Husain ibn Ubaidillah ibn Khasib, Ali Ibrahim ibn Abd al-Majid and others. While his students were Umar ibn Ahmad ibn Usman ibn Ahmad ibn Muhammad ibn Ayyub ibn Yazdad ibn Siraj ibn Abdirrahman, Muhammad ibn al-Abbas ibn Muhammad ibn Zakariyya ibn Yahya ibn Ma'ad and others. Al-Khatib al-Bahdadi (d. $463 \mathrm{H}$ ) and Muhammad Ismail alWarraq considered him to have been a monk for Hasyim who wara ', righteousness and religious understanding (kana rahiban bai Hasyim silahan wadinan wa war'an).

4) Ali ibn Ibrahim al-Wasiti, his real name is Ali ibn Ibrahim ibn Abd al-Majid. He died in $274 \mathrm{AH}$ and was in the 11th tabaqah class and was considered tsiqah. He lives in Baghdad and has the ratios of al-Yaskuri, as-Shibani and al-Wasiti. The teachers were Mansur ibn al-Muhajir, Muhammad ibn Abi Nu'aim, Salim ibn Salam and others. While the students were Abd al-Wahid ibn Muhammad ibn Harun ibn Muhammad ibn Harun ibn Muhammad ibn Abdillah ibn Muhammad ibn Ali ibn Abdillah ibn al-Abbas, Usman ibn Ahmad ibn Abdullah ibn Yazid, Aslam ibn Sahal ibn Salam ibn Ziyad ibn Habib and etc. Ad-Daruquthni and az-Zahabi rated it tsiqah, Abu Hatim ar-Razi and ibn Abi Hatim ar-Razi rated it as suduq while Ibn Hajar al-Asqalani considered it tsiqah mutqin.

5) Mansur ibn al-Muhajir is included in the 10th tabaqah, the year he died and lived at the Wasit, is considered maqbul (narration of his hadith). The teachers were Abu an-Nadr, Ismail ibn Hammad ibn al-Hasan ibn Hammad, Abdurrahman ibn Abdullah ibn Kaisani and others. His students were Ali ibn Ibrahim ibn Abd al-Majid, Muhamamd ibn Ismail ibn al-Bukhtari and others. Ibn Hajar al-Asqalani considered him mastur.

6) Abi an-Nadri al-Abbar, his real name is Abu an-Nadr. He is included in the 6th tabaqah and is considered majhul al-hal. His teacher was Anas bin Malik and his student was Mansur ibn al-Muhajir. There is no criticism or any information regarding his narrative in terms of hadith.

7) Anas ibn Malik, his real name is Anas ibn Malik ibn An-Nadr ibn Damdami ibn Zaid ibn Haram. He belonged to the 1st tabaqah and lived in Basra. Some say he died in 70 or $67 \mathrm{AH}$. He had 64 teachers, among whom were Abu Taibah, Aksam ibn Jawn, Anas ibn Abi Mursad and others. While his students were Abu an-Nadr, Abu Bakr, and others. A number of scholars of hadith criticized him as an assistant to the Prophet, a well-known companion of the Prophet.

From the explanation, it can be concluded that each narrator has the possibility of meeting each other in the bond between teacher and student. This can be seen from the data on the names of teachers and students in the narrator's biographical information. It must be admitted that there are some narrators whose narrative qualities are not known, such as Abu an-Nazr and Mansur ibn al-Muhajir. Imam al-Ajluni (d. $1162 \mathrm{H}$ ) in Kasyf al-Khafa mentions that the two narrators are unknown (la ya'rifani) and also mentions that al-Khatib al-Baghdadi negated this hadith which was narrated through Ibn Abbas's sanad. The same thing was conveyed by as-Sakhawi (d. $902 \mathrm{H})$ in al-Maqasid al-Hasanah it is known that the two narrators are unknown and their hadith is munkar (wa al-hadis munkar) (As-Sakhāwi \& Abdurrahman, 1985).

Seeing from the form of his matan, the Prophet's hadiths are in the form of jam'l al-kalim (a short expression, but full of meaning), tamsil (parable), symbolic language (ramzi), dialogue language, analogical expression (qiyasi) and others. (Ismail, p. 9). This hadith al-jannatu includes a form of hadith that is jam'l al-kalim by using symbolic devices or analogical expressions, it is almost impossible to understand this hadith textually because there cannot be heaven under mother's feet. This means that it must have or produce its contextual meaning. According to as-Sakhawi, the meaning of this hadith is anna at-tawaddu'li al ummahati sababun li dukhuli al-jannah (actually tawadu to mother is the cause of one's entry into heaven).

There are differences of opinion in assessing the quality of the hadith with these observations, such as a study by Nurcholis Rachman in 2016 in his thesis entitled "Hadith About Heaven Under Mother's Feet (Study of Criticism of Sanad and Matan)" IAIN Surakarta and the results of this research. It was found that the hadith about heaven under the soles of the mother's feet has the status of ahâd hadith with the degree of shahîh lî dzâtihi, while a journal by Hamam Faizin in 2018 conducted a research entitled "Is Heaven Under Mother's Feet? (Contextualization of the Hadith al-jannatu tahta aqdam al-Ummahati) STAI Al- 
Hikmah Jakarta and the results of this study are weak hadith sanad (dhaif) with the status of marfu, which has a high level of honesty, so that it can be used as evidence of syari'iyyah (Faizin, 2018).

To avoid the fame of the fake hadith in society, then Khadher Ahmad, Ishak Hj. Suliaman, Ahmad Shah and Ibrahim Adham argue in presenting an alternative hadith on the primacy of father and mother: Mu'awiyah bin Jahimah has reported that he came to the Prophet, then said: "Verily I want to join the battle of jihad and I came to ask your opinion." Then the Prophet asked: "Do you still have a mother?" He replied: "Yes". Rasulullah said: "... go and worship your mother, because heaven is actually under her feet".

Or other traditions that show the superiority of mothers over fathers: Abu Hurairah said, "A man came to the Prophet and asked," O Messenger of Allah, whom do I need to give more devotion to? ". Rasulullah replied, "Your mother". The man asked again, "then who?". Rasulullah replied, "Your mother". The man asked again, "then who?". Rasulullah replied, "Your mother". The man asked again, "then who?". Rasulullah replied, "Your father".

According to Khadher Ahmad, Ishak Hj. Suliaman, Faisal Ahmad Shah and Ibrahim Adham: "Bringing alternative hadiths on this issue may educate people to understand the hadiths and refer to more valid and trustworthy sources." Displaying hadiths that are still in dispute over quality will create confusion for website visitors and may lead to divisions over disagreements. It would be wiser if what is displayed on the website are authentic traditions or at least hasan traditions in which there are not many differences of opinion.

\section{CONCLUSION}

From the ten criteria for website development resulting from the research of Khadher Ahmad, Ishak Hj. Suliaman, Faisal Ahmad Shah and Ibrahim Adham, in our opinion, not all of them can be recommended, such as the distribution of hadiths based on the jawi books, it is not necessary to display it on the website because if you want to refer to the context of the books in the archipelago, there will be a lot of things that need to be studied more deeply about their authenticity. and making alternative hadiths to replace false hadiths is also deemed unnecessary because it would be wiser if the hadiths displayed on the website are free from criticism and debate in their practice.

\section{REFERENCE}

Afwadzi, B. (2017). Criticism of Hadith in the Perspective of a Historian. Mut Worried: Scientific Journal of Hadith Tafsir, 7(1), 51. Anam, W. (2016). Maḥmûd Abû Rayyah and Hadith Criticism. Mut Worried Journal of Scientific Tafsir Hadith, 6(1), 1.

Anggito, A., \& Setiawan, J. (2018). Qualitative research methodology. CV Imprint.

As-Sakhāwi, \& Abdurrahman, M. (1985). al-Maqaşid al-Hasanah fi Bayāni cashier min al-Ahadis al-Mustaharah ala al-Alsinah. Beirut: Dar al-Kitab al-Arabi.

Dalimunthe, R. P. (2009). "Syaz" dan permasalahannya. Dipresentasikan Pada Seminar Kelas Mata Kuliah ,Qowaid Al-Tah\} Di> S' Semester I S3 Konsentrasi Hadits PPs UIN Alauddin Makassar Tanggal, 19.

Faizin, H. (2018). Is Heaven Under Mother's Foot? (Contextualization of the Hadith al-jannatu tahta aqdam al-Ummahati) ". Himah, 19(2).

Ginanjar, T. (2014). Rahasia Membangun Website Toko Online Berpenghasilan Jutaan Rupiah. Iffahmedia.

Idris. (2020). Permasalahan keaslian Hadits Nabi, dari klasik hingga kontemporer. Prenada Media.

Irham, M. (2011). The History and Development of Criticism of Matn Hadith. Mut Worried: Journal of Scientific Tafsir Hadith, 1(1), 98.

Khadher Ahmad, E. al. (2019). Main Criteria in Hadith Website Development: One Analysis and Reserve. International Muzakarah \& Mu'tamar on Hadith (IMAM 2019). University of Malaya Kuala Lumpur, 1-25.

Lasyin, M. S. (2002). Fathul Mun'im Syarah Shohih Muslim. Cairo: Dar Al-Syuruq, 5(7).

Muslim, S. (2014). Muslim Bin Al-Hajjaj Bin Muslim Al-Qasyiri Al-Naisaburi. Dar Al-Ta'shil, 1(307).

Mustari, M., \& Rahman, M. T. (2012). Pengantar Metode Penelitian. Laksbang Pressindo.

Ridwan Nurrohman, M., \& Kosasih, E. (2010). Discourse of Matan's Criticism: Tashih Mutūn's Approach to the Controversy of the History of the Prophet Muhammad to Turn Ibn Ubay". Diroyah: Journal of Hadith Studies, 5(1), 2.

Sulianta, F., \& Supriatna, N. (2020). DIGITAL CONTENT MODEL AS A BASIS OF CONNECTIVISM KNOWLEDGE LEARNING FOR DIGITAL SOCIETY. PalArch's Journal of Archaeology of Egypt/Egyptology, 17(10), 1118-1137.

Umar, A. (2011). The Cultural Criticism of Ulama Hadith, Historical and Practical Perspectives. Mut Worried: Scientific Journal of Hadith Tafsir, 1(2).

Yunus, F., A. . (2015). The Future of Arabic in Indonesia. Republika Online.

Zuhriah, A., \& Shilviana, K. F. (2020). Kritik Pikiran dan Urgensinya dalam Pembelajaran Hadits. Jurnal IImu Hadits, 3(1).

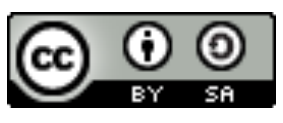

(c) 2021 by the authors. Submitted for possible open access publication under the terms and conditions of the Creative Commons Attribution (CC BY SA) license (http://creativecommons.org/licenses/by-sa/4.0/). 